\title{
Study of Snow Depletion Characteristics at Two Mountainous Watersheds Using NOAA AVHRR Time Series Data
}

\author{
Hyungjin Shin*, Minji Park ${ }^{\star \star}$, Hyosok Chae*, Saetbyul Kim ${ }^{\star \star \star}$ and Seongjoon Kim ${ }^{\star \star \star \dagger}$ \\ *Water Resources Management Research Team, Water Resources Research Center, Korea Water Resources Corporation \\ **Dept. of Water Environment Research, Water Quality Control Center, National Institute of Environmental Research \\ ***Dept. of Civil and Environmental System Engineering, Konkuk University
}

\begin{abstract}
Spatial information of snow cover and depth distribution is a key component for snowmelt runoff modeling. Wide snow cover areas can be extracted from NOAA AVHRR or Terra MODIS satellite images. In this study eight sets of annual snow cover data (1997-2006) in two mountainous watersheds (A: ChungjuDam and B: Soyanggang-Dam) were extracted using NOAA AVHRR images. The distribution of snow depth within the Snow Cover Area (SCA) was generated using snowfall data from ground meteorological observation stations. Snow depletion characteristics for the two watersheds were analyzed snow distribution time series data. The decreased pattern of SCA can be expressed as a logarithmic function; the determination coefficients were 0.62 and 0.68 for the A and B watersheds, respectively. The SCA decreased over $70 \%$ within 10 days from the time of maximum SCA.
\end{abstract}

Key Words : NOAA AVHRR, Snow cover area, Snow depletion, Snowmelt

\section{Introduction}

Understanding the spatial information of snow cover by using just ground measured point data presents many limitations because of an insufficient number of data points and complex topographic characteristics. Remote sensing technologies from satellites have proved very effective in obtaining a wide area of snow cover information. Two of the effective satellite images for snow cover monitoring on a spatio-temporal usefulness and cost-efficiency basis are National
Oceanic and Atmospheric Administration (NOAA) Advanced Very High Resolution Radiometer (AVHRR) and Terra Moderate Resolution Imaging Spectroradiometer (MODIS).

The extent of snow cover has been monitored globally from NOAA AVHRR since the early 1970s. Rango et al. (1983) stated that a spatial resolution of $1.1 \mathrm{~km}$ is sufficient to study if areas larger than 200$500 \mathrm{~km}^{2}$ are targeted; however, an area $500-1000 \mathrm{~km}^{2}$ or larger seems to provide better statistical data. Lucas et al.(1989) used a supervised multispectral classification

Received December 7, 2012; Revised January 4, 2013, Revised January 9, 2013; Accepted January 10, 2013.

Corresponding Author: Seongjoon Kim (kimsj@konkuk.ac.kr)

This is an Open-Access article distributed under the terms of the Creative Commons Attribution Non-Commercial License (http://creativecommons.org/ licenses/ by-nc/3.0) which permits unrestricted non-commercial use, distribution, and reproduction in any medium, provided the original work is properly cited 
to separate snow in AVHRR images by using channels 1,3 and 4. Cracknel (1997) emphasized using AVHRR images to determine the extent of snow cover, recommending a threshold method in snow and cloud separation. Simpson et al . (1998) used a multispectralmultistage method to separate snow and clouds in AVHRR images. They used channels 2, 3,4 and 5 and proposed a three-stage algorithm. This method separates out snow and clouds from the data and then separates the snow from the clouds data. Shin et al. (2007) studied the snowmelt parameters of five major river basins in South Korea to model watershed hydrologic processes during the winter and spring periods. Yeom et al. (2009) tried to develop an algorithm for detecting snow cover area with MODIS data. Kim et al. (2011) attempted to develop a snowfall retrieval algorithm using a combination of radiometer and cloud radar data. Park et al. (2012) analyzed timeseries changes in snow cover quantitatively and predicted the vanishing point of snow cover statistically using Landsat satellite images.

In South Korea as in some other countries, there is a near-term projected deficiency of water resources because of the impact of on-going climate change increasing water demand. Thus, we need to secure additional water resources, while making efforts to conserve water or make other adaptations for the future. Snowfall in South Korea is uneven, being extensive in some areas like the Northeast from December to April. During the past several years, heavy snowfall in that area has caused severe damage. Snowmelt water during winter and spring can provide a useful water resource via the water storage of large dams especially in the Northeastern mountainous area. To estimate how much snowmelt stream water can contribute to the a dam's water storage, it is necessary to identify the spatial snow cover and its temporal depletion and parameterize the characteristics for snowmelt hydrology.

The objective of this study is to identify snow depletion characteristics from the snow depth distribution which is generated using the NOAA AVHRR snow cover area and the ground measured snowfall data. For two mountainous watersheds (A: $6661.5 \mathrm{~km}^{2}$ and B: $2,694.4 \mathrm{~km}^{2}$ ) located in the northeastern part of South Korea, eight sets (19972006) of snow cover were extracted annually from December to April and the snow depth distribution of that area was generated by interpolating seven (A watershed) and five (B watershed) ground measured snowfall data, respectively. Using time series data of snow depth distribution, snow depletion characteristics of each watershed were analyzed as representative functions.

\section{Materials and Methods}

\section{1) The Study Watersheds}

Two mountainous watersheds located in the northeastern part of South Korea were selected. The location and stream networks are shown in Fig. 1.

Watershed ' $\mathrm{A}$ ' of $6661.5 \mathrm{~km}^{2}$ area lies within the latitude-longitude range of $36.8^{\circ} \mathrm{N}-37.8^{\circ} \mathrm{N}$ and $127.9^{\circ}$ E-129.0 $0^{\circ}$ E. At the watershed outlet, Chungju Dam (97.5 $\mathrm{m}$ in height, $447.0 \mathrm{~m}$ in length with 9.7 million $\mathrm{m}^{3}$ of storage volume) is located. Average annual temperature, precipitation, and snowfall are $9.6^{\circ} \mathrm{C}$, $1522.6 \mathrm{~mm}$, and $100.3 \mathrm{~mm}$, respectively. The watershed's vegetation cover consists of $82.2 \%$ forests, $1.8 \%$ upland crops, and $10.3 \%$ paddy fields. The 2000 year land use was obtained from Water Resources Management Information System (WAMIS).

Watershed ' $\mathrm{B}$ ' of $2,694.4 \mathrm{~km}^{2}$ area lies within the latitude-longitude range of $37.7^{\circ} \mathrm{N}-38.5^{\circ} \mathrm{N}$ and $127.8^{\circ}$ E-128.7 E. Soyanggang Dam (123.0 $\mathrm{m}$ in height, $530.0 \mathrm{~m}$ in length with 9.6 million $\mathrm{m}^{3}$ of storage volume) is located at the watershed outlet. Average annual temperature, precipitation, and snowfall are $10.0^{\circ} \mathrm{C}, 1281.4 \mathrm{~mm}$, and $146.0 \mathrm{~mm}$, respectively. Its 


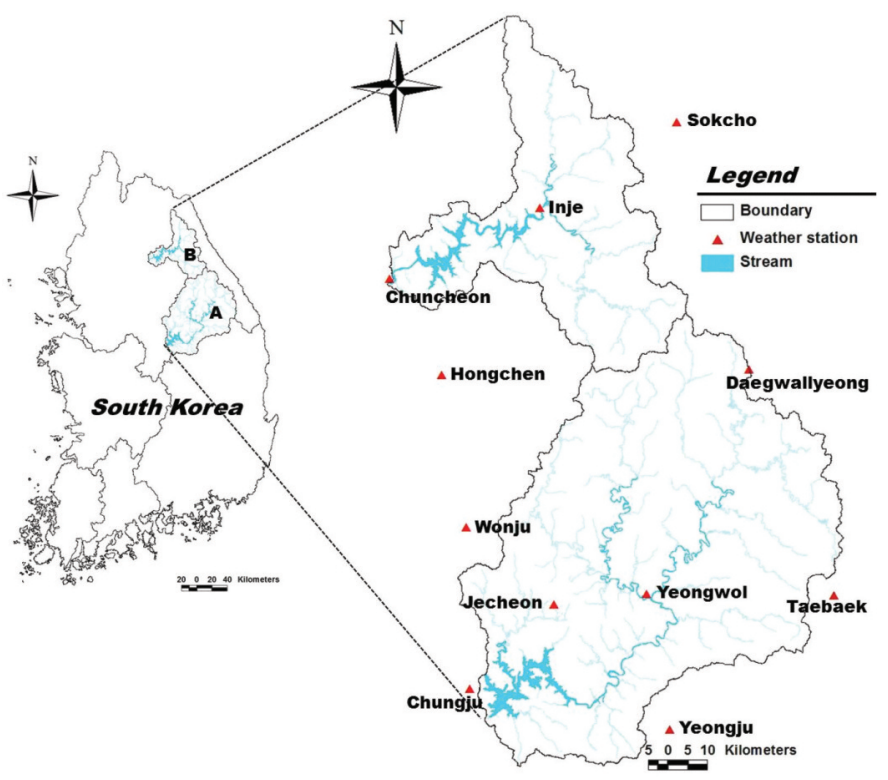

Fig. 1. The study watersheds (A: Chungju-dam watershed, B: Soyanggang-dam watershed).

watershed's vegetation cover is $92.0 \%$ forests, $2.7 \%$ upland crops, and $2.0 \%$ paddy fields. A total of 11 weather stations are located either close to or within the two watersheds. The seven and five weather stations of each watershed are seen in Fig. 1.

\section{2) Snow cover and depth distribution from NOAA AVHRR}

The NOAA satellite was developed for meteorological observations. This satellite has a AVHRR sensor with five channels ranging from $0.58 \mu \mathrm{m}$ to $12.5 \mu \mathrm{m}$. Temporal resolution of this satellite is 16 cycles per day; spatial resolution of the image is $1.1 \mathrm{~km}$ by 1.1 $\mathrm{km}$. In this study, eight sets (1997-1998, 1999-2000, 2000-2001, 2001-2002, 2002-2003, 2003-2004, 20042005, and 2005-2006) of AVHRR images during the snowfall period (December to April) were obtained from the Korea Meteorological Administration (KMA, http://www.kma.go.kr) and used to extract snow cover area information of the watershed.

Several algorithms have been developed for snow monitoring from optical sensors including the multispectral thresholds classification method (Allen $e t$ al., 1990; Gesell, 1989; Harrison \& Lucas, 1989; Kazama, 1995; Liu et al., 1999; Romanov et al., 2000). In this study the Kazama method was adopted. The extraction procedure of a snow cover area from an image is as follows. First, the images were geo-rectified to the Transverse Mercator (TM) coordinate system using 19 Ground Control Points (GCPs) along the Korean Peninsula boundary. Second, it was necessary to transfer the pixel values into albedo because the pixels of raw images include just reflectance values of surface objects. Third, the snow cover area was extracted using channels 1,3 and 4 of the NOAA AVHRR image as in Fig. 2. Channel 1 can detect snow including the cloud area. Channel 4 provides temperature information for detecting high clouds; and channel 3 can detect low clouds. The extracted snow cover area of the image was validated using ground snow data at 69 meteorological stations in South Korea until the 69 pixels satisfied the snow status within a $5 \%$ error.

To generate the snow depth distribution within the snow cover area extracted from the image, snowfall data from the meteorological ground stations were used 


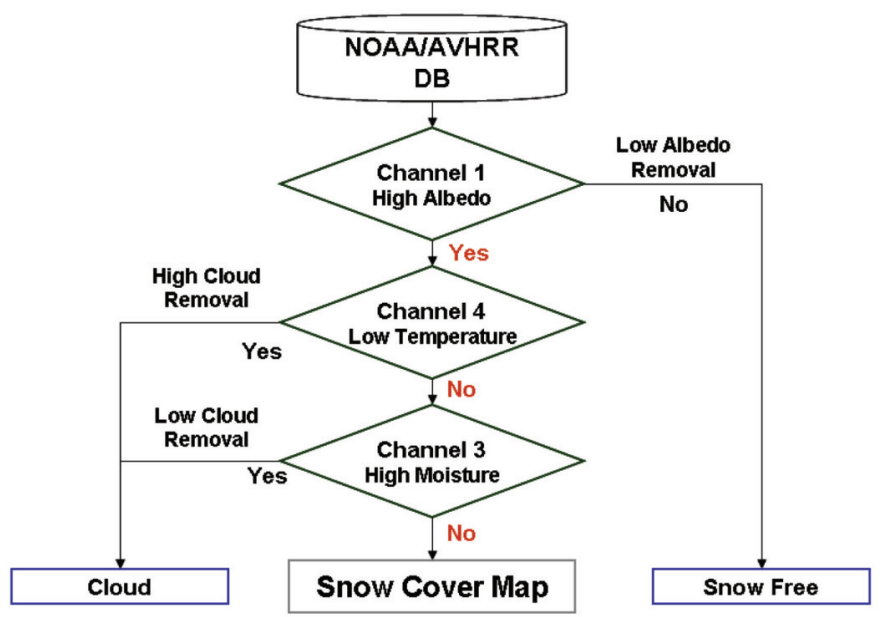

Fig. 2. Algorithm for snow cover area classification.

and spatially interpolated to the extracted snow cover areas. Inverse Distance Weighting (IDW) (Burrough and McDonnell, 1998) was applied for the interpolation as in Eq. (1). Finally, the results were masked for each watershed boundary.

$$
Z\left(x_{0}\right)=\frac{\sum_{i=1}^{n} Z\left(x_{i}\right) d_{i j^{-m}}}{\sum_{i=1}^{n} d_{i j^{-m}}}
$$

where $\mathrm{Z}\left(\mathrm{x}_{0}\right)$ is the point to be estimated; $\mathrm{Z}\left(\mathrm{x}_{\mathrm{i}}\right)$ represents the control value for the $i^{\text {th }}$ sample point; and $\mathrm{d}_{\mathrm{ij}}{ }^{-\mathrm{m}}$ is a weight that determines the relative importance of the individual control point $\mathrm{Z}\left(\mathrm{x}_{\mathrm{i}}\right)$ in the interpolation procedure; $\mathrm{x}_{0}$ is the estimation point and $\mathrm{x}_{\mathrm{i}}$ are the data points within a selected neighborhood method. The weights $(m)$ are related to distance by $\mathrm{d}_{\mathrm{ij}}$, which is the distance between the estimation point and the data points. The IDW formula has the effect of conferring relatively large weight on the points close to the interpolation point, while those far away exert little influence. The higher the weight used, the more influence points close to $\mathrm{x}_{0}$ are given.

\section{Results and Discussion}

\section{1) Snow Cover Area (SCA) extraction}

Following the extraction procedure of a snow cover area with the NOAA AVHRR images, the snow cover area was extracted for the two watersheds. A total of 108 images were selected. Table 1 summarizes the threshold values of each channel to extract the snow

Table 1. Threshold value ranges and averages

\begin{tabular}{c|c|c|c|c}
\hline \hline \multirow{2}{*}{ Set } & \multicolumn{3}{|c|}{ Threshold value } & \multirow{2}{*}{ Number of Images } \\
\cline { 2 - 5 } & Channel 1 & Channel 4 & Channel 3 & 17 \\
\hline $1997-1998$ & $5 \sim 8[7]$ & $-14 \sim-3[-8]$ & $-6 \sim 10[4]$ & 8 \\
\hline $1999-2000$ & $2 \sim 6[4]$ & $-14 \sim 0[-8]$ & $-1 \sim 15[3]$ & 7 \\
\hline $2000-2001$ & $4 \sim 20[8]$ & $-20 \sim 30[-5.5]$ & $-15 \sim 14[7]$ & 17 \\
\hline $2001-2002$ & $13 \sim 20[17]$ & $-8 \sim 0[-3]$ & $6 \sim 10[9]$ & 9 \\
\hline $2002-2003$ & $12 \sim 21[17]$ & $-2 \sim 6[0]$ & $5 \sim 25[10]$ & 12 \\
\hline $2003-2004$ & $10 \sim 25[16]$ & $-15 \sim 1[-7]$ & $5 \sim 13[8]$ & 21 \\
\hline $2004-2005$ & $10 \sim 22[17]$ & $-12 \sim-6[-10]$ & $5 \sim 15[10]$ & 17 \\
\hline $2005-2006$ & $14 \sim 25[19]$ & $-8 \sim-12[-9]$ & $8 \sim 14[10]$ & 108 \\
\hline Total [Average] & $2 \sim 25[10]$ & $-20 \sim 30[-5]$ & $-15 \sim 25[6]$ & \\
\hline \hline
\end{tabular}




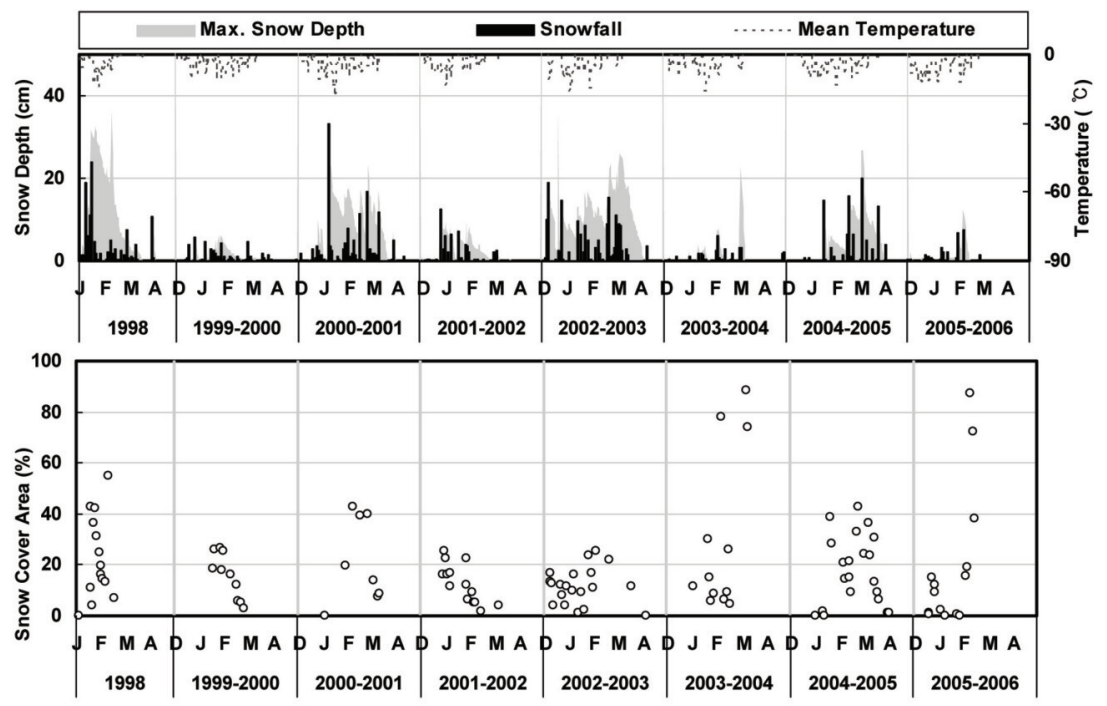

Fig. 3. The extracted snow cover area for eight sets in A watershed.

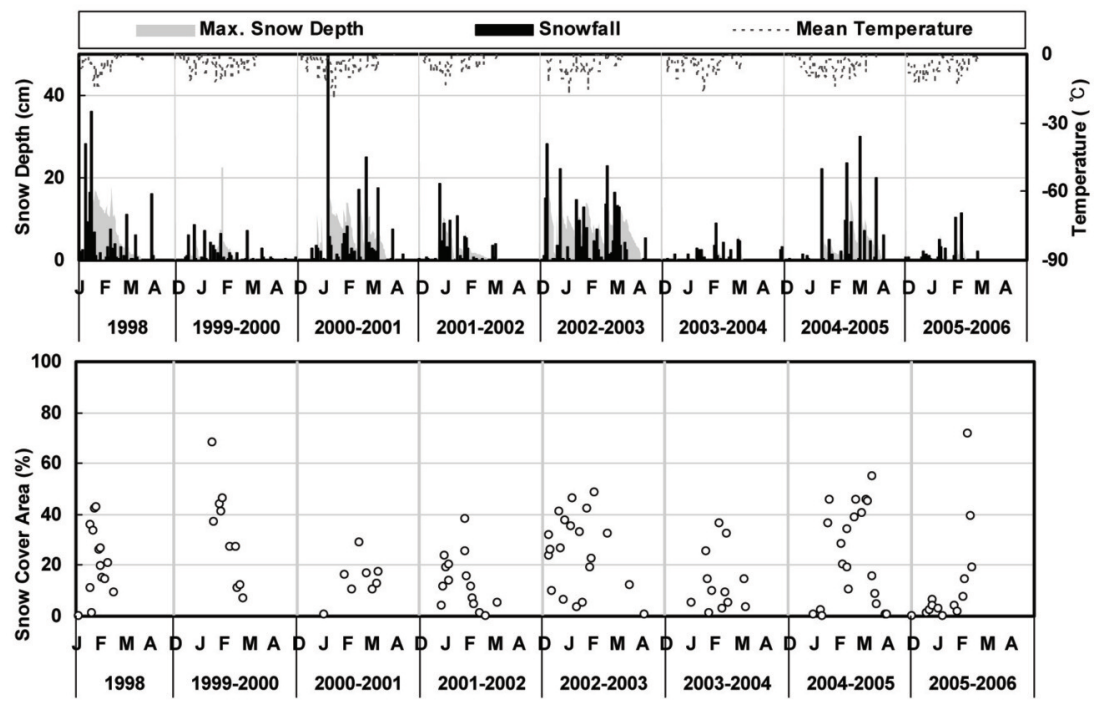

Fig. 4. The extracted snow cover area for eight sets in B watershed.

cover area for the eight sets of AVHRR images.

The channel threshold values of each image varied considerably. The threshold value of channel 4 showed the largest deviation ranging from - 20 to 30. The threshold value of channels 1 and 3 showed deviation ranging from 2 and - 15 to 25 and 25 , respectively. This means that the low and high cloud removal from snow are more sensitive than the snow free area removal from snow including the cloud area. Fig. 3 and 4 show the summary of eight sets of extracted snow cover areas for the A and B watersheds. Snow cover of these watersheds usually lasted from January to March, almost disappearing in April.

\section{2) Generated snow depth distributions using ground measured snowfall data}

Snow depth distributions for the extracted snow cover area were generated using 11 ground measured snowfall data for the two watersheds by applying the IDW interpolation method. Fig. 5 and 6 show the 

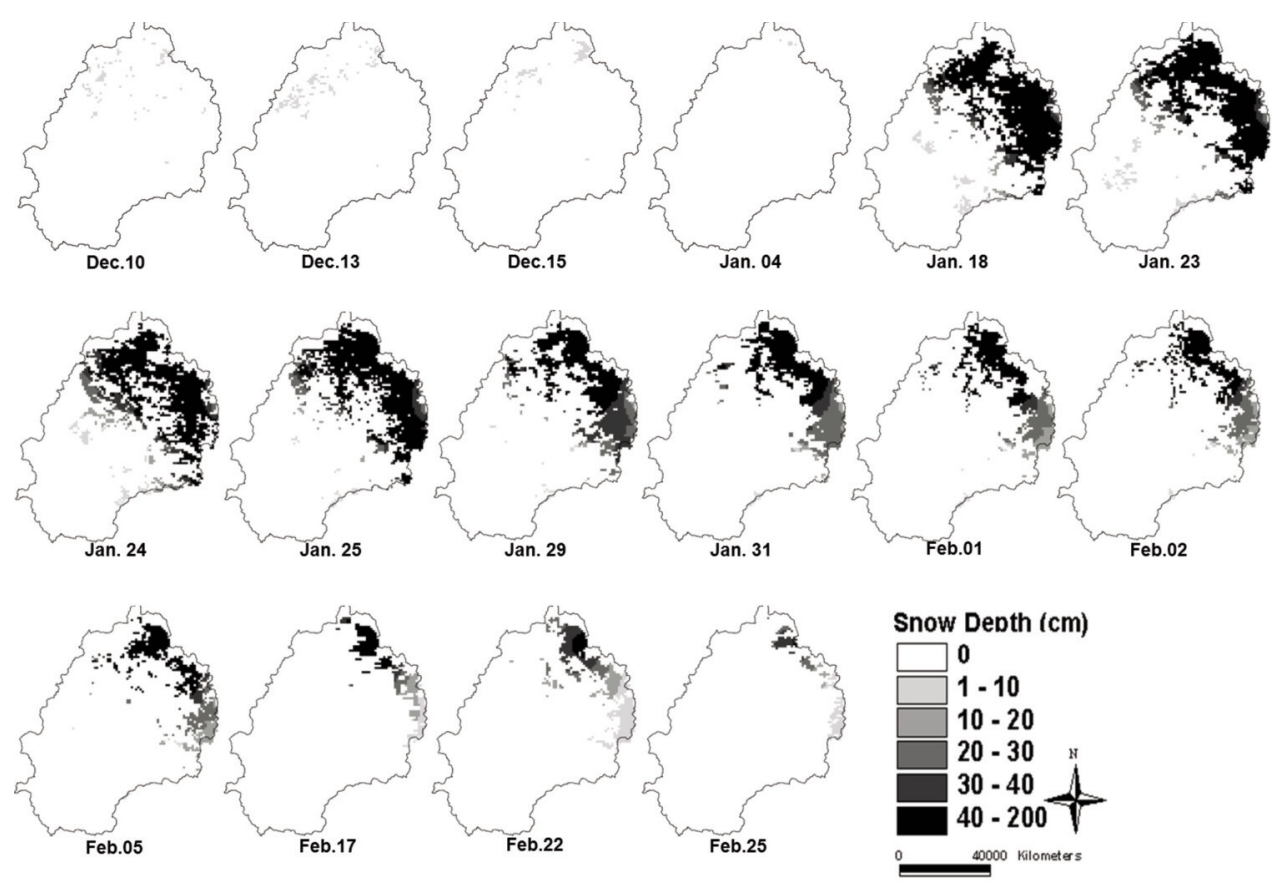

Fig. 5. The 1997-1998 generated snow depth distribution within the NOAA AVHRR SCA using the ground-measured snowfall data (A: Chungju-dam watershed).

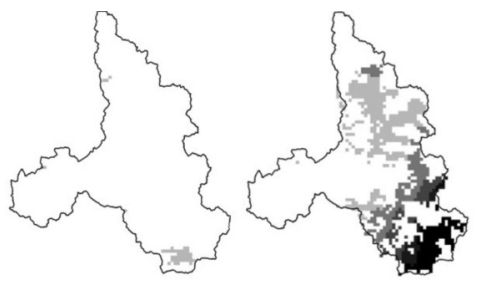

Dec.15

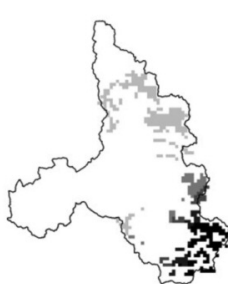

Feb.01
Jan. 18

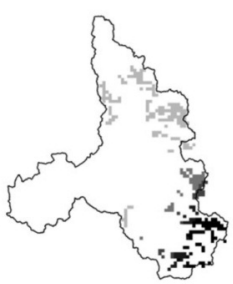

Feb.02

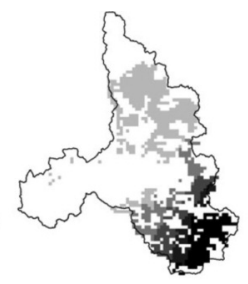

Jan. 24

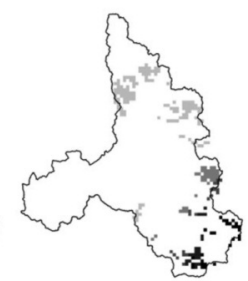

Feb.05

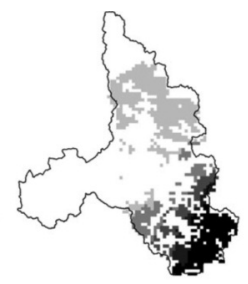

Jan. 25

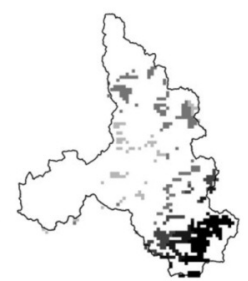

Feb.10

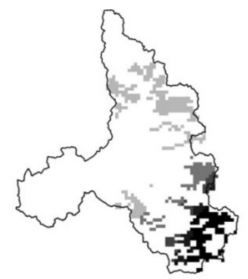

Jan. 29

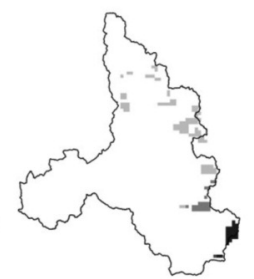

Feb.17

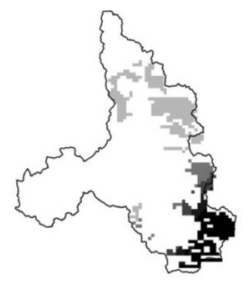

Jan. 31

Fig. 6. The 1997-1998 generated snow depth distribution within the NOAA AVHRR SCA using the ground-measured snowfall data (B: Soyanggang-dam watershed).

sample of generated snow depth distribution in the 1997-1998 set (A: Chungju-dam watershed, B: Soyanggang-dam watershed).

As shown in Fig. 5 and 6, the snowfall of each watershed covered the north and northeast of the A watershed and the south and southeast of the B watershed. During the snow depletion periods, the snow cover was maintained at the right part of mountain. These are have high elevation areas with the land cover being forest, especially coniferous. 


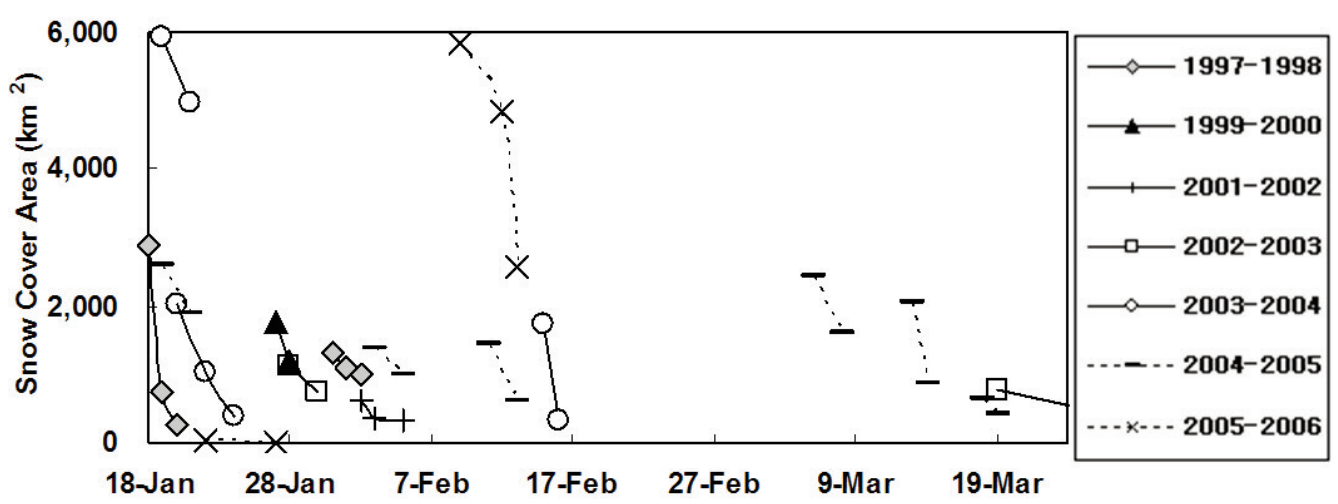

A

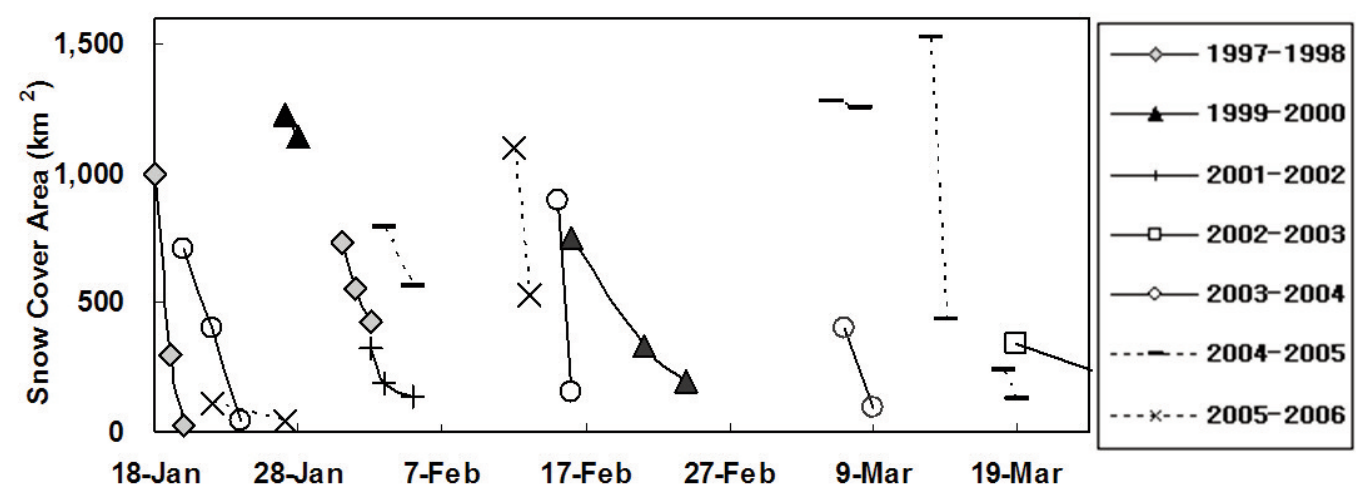

B

Fig. 7. Snow depletion curves from the maximum snow cover area of each data set (A: Chungju-dam watershed, B: Soyanggangdam watershed).

Table 2. Snow depletion curves for two watersheds

\begin{tabular}{c|c|c}
\hline \hline Watershed & Regression equation & $\mathrm{R}^{2}$ \\
\hline Soyanggang-dam & $\mathrm{y}=-0.38 \times \ln (\mathrm{x})+0.97$ & 0.62 \\
\hline Chungju-dam & $\mathrm{y}=-0.41 \times \ln (\mathrm{x})+0.97$ & 0.68 \\
\hline \hline
\end{tabular}

$\mathrm{y}$ : the ratio of snow cover area, $\mathrm{x}$ : the number of days after the maximum snow cover area

\section{3) Derivation of the snow depletion curve}

Through using the data for the entire eight sets, snow depletion curves for the two watersheds were derived plotting the ratio of the snow cover area as the vertical axis and the number of days after of the maximum snow cover area as the horizontal axis. Fig. 7 shows the data sets used for the derivation of the snow depletion curve for each watershed; Table 3 and Fig. 8 show the derived results.
The snow depletion curve can be expressed as a logarithmic decay function with the determination of coefficients of 0.62 and 0.68 for A and B watersheds respectively. The snow cover was depleted by 11 days to less than $5 \%$ from the maximum snow cover of $100 \%$. The snowmelt of a watershed is affected by diverse factors such as solar radiation, temperature, wind speed, slope aspect and elevation. This kind of depletion curve is necessary for snowmelt modeling. Many hydrological models require the snow depletion 


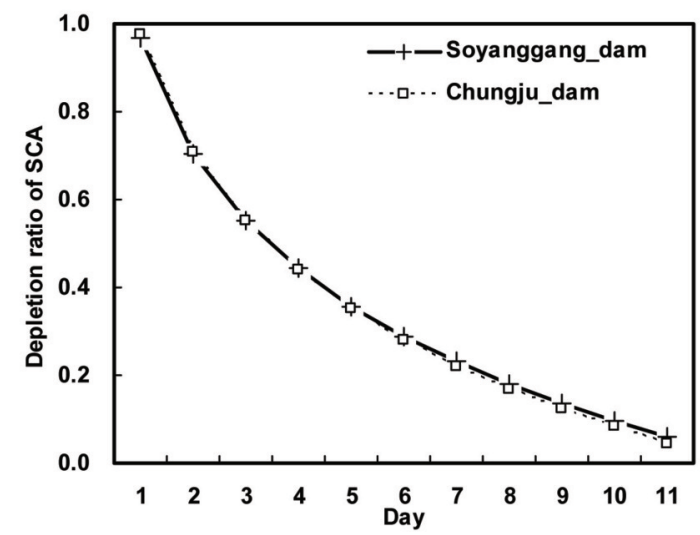

Fig. 8. Snow depletion curves from the maximum snow cover for two watersheds.

curve for snowmelt simulation as a model parameter.

\section{4) Temperature lapse rate}

Most snowmelt runoff models handle spatial and temporal variations resulting from elevation by incorporating elevation zones (Rango and Martinec, 1979). Elevation strongly influences both snow accumulation and melting in mountainous watersheds (Pomeroy and Burn, 2001). To accurately represent temperature throughout an elevationally diverse subbasin, the temperature lapse rate was applied to each elevation zone (Martinec and Rango, 1986; Hartman et al., 1999). Atmospheric temperatures within the troposphere generally decrease with elevation. Using 30 years (1981-2010) of temperature data from 10 meteorological stations, the monthly temperature lapse rates were estimated at $-7.8^{\circ} \mathrm{C} / \mathrm{km} \sim-3.1^{\circ} \mathrm{C} / \mathrm{km}$ for the A watershed and $-7.6^{\circ} \mathrm{C} / \mathrm{km} \sim-5.9^{\circ} \mathrm{C} / \mathrm{km}$ for $\mathrm{B}$ the watershed respectively (Fig. 9).

\section{Conclusion}

This study attempted to identify snow depletion characteristics using NOAA AVHRR snow cover areas. For two mountainous watersheds (A: $6661.5 \mathrm{~km}^{2}$ and B: 2,694.4 $\mathrm{km}^{2}$ ) located in the northeastern part of
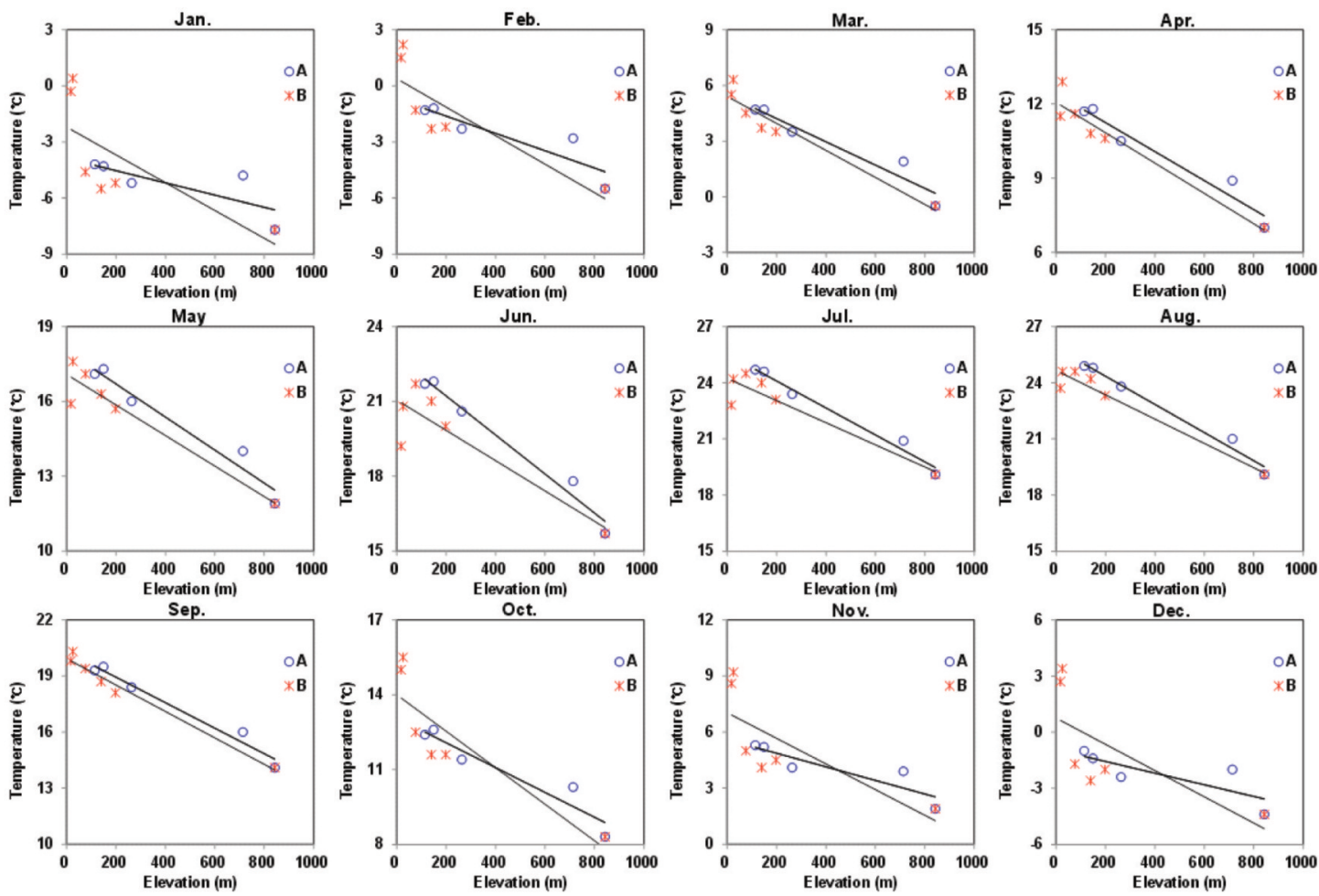

Fig. 9. Mean monthly temperature vs. elevation (A: Chungju-dam watershed, B: Soyanggang-dam watershed). 
South Korea, eight sets (1997-2006) of snow cover data were extracted from the December to April data for each year. Using time series data for the snow cover area, the snow depletion curve was expressed as a logarithmic decay function with the determination of coefficients of 0.62 and 0.68 for the A and B watersheds, respectively. The snow cover at 11 days was depleted below 5\% from the maximum snow cover.

\section{Acknowledgments}

This research was supported by a grant (11-TI-C06) from Advanced Water Management Research Program funded by Ministry of Land, Infrastructure and Transport of Korean government.

\section{References}

Allen, R.C., P.A. Durkee and C.H. Wash, 1990. Snow/cloud discrimination with multi-spectral satellite measurements, Journal of Applied Meteorology, 29: 994-1004.

Burrough, P.A. and R.A. McDonnell, 1998. Creating continuous surfaces from point data, In: Burrough, P.A., Goodchild, M.F., McDonnell, R.A., Switzer, P., Worboys, M.(Eds.), Principles of Geographic Information Systems, Oxford University Press, Oxford, UK.

Cracknel, P., 1997. The advanced very high resolution radiometer, Taylor and Francis Pub.

Gesell, G., 1989. An algorithm for snow and ice detection using AVHRR data, An extension to the APOLLO software package, International Journal of Remote Sensing, 10: 897-905.

Harrison, A. and R. Lucas, 1989. Multi-spectral classification of snow using NOAA AVHRR imagery, International Journal of Remote
Sensing, 10: 907-916.

Hartman, M.D., J.S. Baron, R.B. Lammers, D.W. Cline, L.E. Band, G.E. Liston and C. Tague, 1999. Simulations of snow distribution and hydrology in a mountain basin, Water Resour. Res., 35(5): 1587-1603.

Kim, Y.S., N.R. Kim and K.W. Park, 2011. Development of snowfall retrieval algorithm by combining measurements form CloudSat, AQUA and NOAA satellites for the Korean peninsula, Korean Journal of Remote Sensing, 27(3): 277-288.

Liu, Y., L. Wang and S. Yazaki, 1999. Snow cover monitoring with AVHRR data, Recent Progress in Studies of Asian Monsoon Mechanism, Chinese Meteorological Press. :92102.

Lucas, R.M., A.W. Harrison and E.C. Barrett, 1989 A multispectral snow area algorithm for operational 7-day snow cover monitoring, Remote Sensing and Large Scale Global Processes, Proc. IAHS 3rd Int. Assembly, MD, IAHS Pub. 186: 161166.

Martinec, J. and A. Rango, 1986. Parameter values for snowmelt runoff models, J. Hydrol., 84: 197219.

Park, S.H., M.J. Lee and H.S. Jung, 2012. Analysis on the snow cover variations at Mt. Kilimanjaro using Landsat satellite images, Korean Journal of Remote Sensing , 28(4): 409-420. (in Korean with English abstract)

Pomeroy, J.W. and E. Burn, 2001. Physical properties of snow, In: Snow Ecology: An interdisciplinary examination of snow-covered ecosystems, $\mathrm{H}$. Jones, J.W. Pomeroy, D.A. Walker, and R.W. Hoham (Editors). Cambridge University Press, London, :45-118.

Rango, A. and J. Martinec, 1979. Application of a snowmelt-runoff model using landsat data, Nord. Hydrol., 10: 228-235. 
Rango, A., J. Martinec, J. Forster and D. Marks, 1983. Resolution in operational remote sensing of snow cover, IAHS Publ. 145: 371-381.

Romanov, P., G. Gutman and I. Csiszar, 2000. Automated monitoring of snow cover over North America with multispectral satellite data, Journal of Applied Meteorology, 39: 18661880.

Shin, H.J., G.A. Park and S.J. Kim, 2007. Extraction of snowmelt parameters using NOAA AVHRR and GIS technique for 5 river basins in South Korea, Korean Journal of Remote Sensing, 23(2): 119-124. (in Korean with English abstract)

Simpson, J.J., J.R. Stitt and M. Sienko, 1998. Improved estimates of the aerial extent of snow cover from AVHRR Data, Journal of Hydrology, 204: 1-23.

Yeom, J.M., K.S. Han and G.L. Lee, 2009. The characteristics of visible reflectance and infra red band over snow cover area, Korean Journal of Remote Sensing, 25(2): 193-203. (in Korean with English abstract) 